\title{
POSSIBLE RÔLE OF PROLACTIN DURING THE OESTROUS CYCLE AND GESTATION IN THE EWE
}

\author{
G. KANN AND R. DENAMUR* \\ Laboratoire de Physiologie de la Lactation, Institut National de la \\ Recherche Agronomique, C.N.R.Z., 78350 Jouy-en-Fosas, \\ France
}

\section{INTRODUGTION}

Stricker \& Gruether $(1928,1929)$ were the first to observe that whole pituitary extracts could initiate lactation in pseudopregnant ovariectomized rabbits. Greatly assisted by the many advantages of the specific pigeon crop sac response for isolation and quantitative assay of the effective protein, Riddle, Bates \& Dykshorn (1933) isolated it and named it 'prolactin'. Since this early work, prolactin has been shown to have an important luteotrophic rôle in many species. In this rôle it is usually associated with LH.

In studying the part played by prolactin in reproductive processes, we have investigated its secretion throughout the oestrous cycle and during pregnancy in the sheep, and have studied the effects of replacement therapy in hypophysectomized and pituitary stalk-sectioned ewes.

\section{MATERIAL AND METHODS}

\section{Animals}

All the experiments have been carried out on ewes of the 'Préalpes du Sud' breed. They were accustomed to handling for several days before experiments involving blood sampling, thus reducing possible prolactin surges due to stress.

For the study of prolactin secretion, the cycling ewes were tested for oestrus every $2 \mathrm{hr}$ with the aid of a vasectomized ram. Coitus was prevented because mating sometimes causes a prolactin surge (Cumming, Brown, Goding, Bryant \& Greenwood, 1972). The regularity of the oestrous cycles of the animals had been observed for several weeks previously. Blood samples were collected every hour during the 3 to 4 days around oestrus, and twice a day during the rest of the cycle.

During pregnancy, prolactin secretion, as well as that of $\mathrm{LH}$, oestradiol-17 $\beta$ and progesterone, was studied in seven primiparous ewes. Daily blood samples were taken from mating to Day 100 of pregnancy, then three times a day $(07.00,11.00$ and 16.00 hours) up to parturition (Kann, Habert \& Denamur, 1973).

\section{Surgical techniques}

Conditions of anaesthesia, stalk section, hysterectomy and hypophysectomy

\footnotetext{
* Deceased.
} 
have been previously described (Denamur, Martinet \& Short, 1966, 1970; Denamur, 1968). Particular attention has been given to complete hypophysectomy including destruction of the pars tuberalis (Denamur et al., 1973).

\section{Ovine hormones}

These were supplied by the N.I.H. (FSH-S1, LHS8, prolactin PS6, PS7) or prepared by the C.N.R.S. (LH-M3) or the Byla Co. (prolactin-20 i.u./mg, STH-l i.u./mg).

Some batches of prolactin were treated at $100^{\circ} \mathrm{C}, \mathrm{pH} 7 \cdot 0$, for $30 \mathrm{~min}$ to eliminate LH and STH contaminants (Lyons, Li \& Johnson, 1958). For some cultures in vitro, the latter contaminant was completely eliminated by DEAE cellulose column chromatography.

A solution of ovine $\mathrm{LH}$, prepared twice a day and stored at $+4^{\circ} \mathrm{C}$, was administered by intrajugular perfusion using a Technicon pump 1-SS at a rhythm of $6 \mathrm{ml} / \mathrm{hr}$. Prolactin was administered by intramuscular injection four times a day. Prolactin levels higher than $30 \mathrm{ng} / \mathrm{ml}$ may be constantly maintained with a total dose of 250 i.u./day in an hypophysectomized animal.

\section{Antibodies}

An anti-ovine $\mathrm{LH}$ antibody was obtained by immunizing a mare with ovine LH.

The daily subcutaneous injection of this antibody into cycling ewes from $72 \mathrm{hr}$ before the presumed date of oestrus $(20 \mathrm{ml} /$ day/animal $)$ hinders action of the preovulatory LH peak, oestrus does not occur, and ovulation does not take place as long as the immunoserum is administered.

An ovine antiprolactin antibody was prepared from a stallion using the Byla Co. ovine prolactin. To test the immunologic activity of the serum, we used two techniques: it is appropriate for use in radioimmunologic determination of ovine prolactin and at present is used for the heterologous determination of human prolactin. Moreover, in an in-vitro system of ovine mammary gland tissue culture (90 days of pregnancy) $0.5 \mathrm{ml}$ of this antibody at $1 / 10$ dilution inhibits the specific lactogenic action of at least $50 \mu \mathrm{g}$ of prolactin (C. Jeulin, personal communication).

These two antibodies proved to be specific, and anti-prolactin immunoserum in particular does not bind any radioactive ovine LH. Anti-ovine LH antibody does not cross react with labelled prolactin.

\section{Prolactin inhibitor}

Ergocryptine (CB-154, Sandoz) was administered in an alcohol-tartaric acid solution at a dose of $1 \mathrm{mg} /$ day by subcutaneous injections.

\section{Radioimmunoassays}

The radioimmunological techniques used for prolactin and LH have already been published (Kann, 1971a). The results of the prolactin determinations are expressed in $\mathrm{ng} / \mathrm{ml}$ of PS7 NIH (24 i.u./mg). 


\section{RESULTS}

PROLAGTIN DURING THE OESTROUS GYCLE

Variations in plasma prolactin concentration during the oestrous cycle of the ewe have already been described by one of us (Kann, 1971b). Between Days -10 and -3 preceding oestrus, prolactin plasma levels varied from 10 to $40 \mathrm{ng} / \mathrm{ml}$ (Text-fig. 1). In the 24 to $48 \mathrm{hr}$ before oestrus there is a considerable rise in the plasma prolactin levels. One or two peaks during $20 \mathrm{hr}$ are observed with maximal values of 200 to $300 \mathrm{ng} / \mathrm{ml}$. These high levels correspond to a

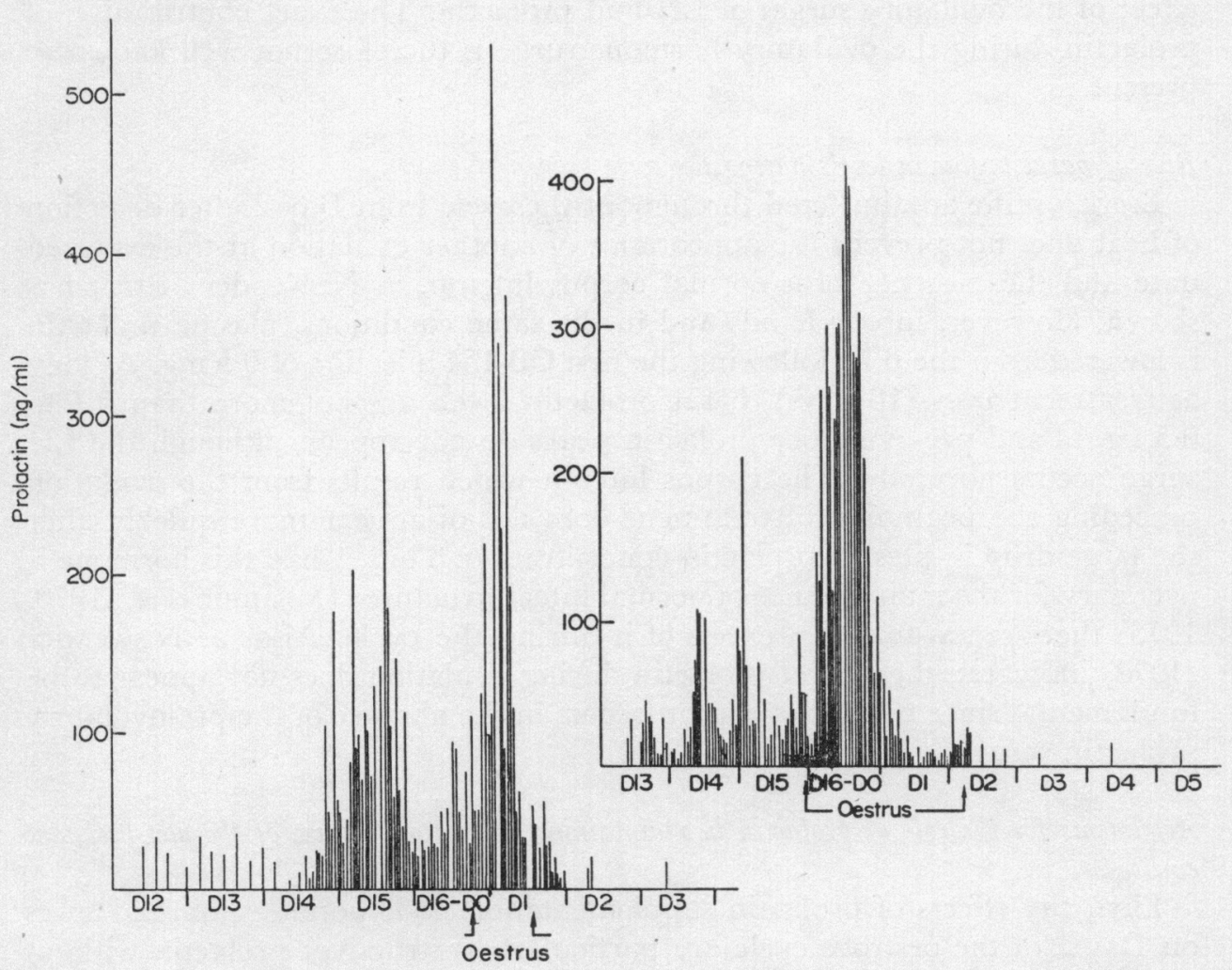

TeXT-FIG. 1. Prolactin concentrations in plasma during the oestrous cycle in two ewes.

simultaneous increase of blood oestrogens (Terqui, Dray \& Cotta, 1973). At that time, progesteronaemia also drops (Bjersing \& his co-authors, 1972). After a temporary return to basic levels (10 to $40 \mathrm{ng} / \mathrm{ml}$ ), there is a prolactin surge 3 to $5 \mathrm{hr}$ after the onset of oestrus.

The highest values are reached at 500 to $600 \mathrm{ng} / \mathrm{ml}$ and then smaller surges occur during the progressive return to the basic level $(10$ to $40 \mathrm{ng} / \mathrm{ml})$, which is reached $30 \mathrm{hr}$ after the onset of oestrus.

There is a period of several hours when low values of 7 to $10 \mathrm{ng} / \mathrm{ml}$ are measured, then by Day 2 or 3 of the cycle, the values return to the basic levels observed during the 'interoestrous' period. 
The 'preovulatory' surge and prolactin luteotrophic activity

Limited development of the corpus luteum occurs in ewes hypophysectomized $40 \mathrm{hr}$ after the onset of oestrus. Ten days later, the CL weights are 30 to $40 \%$ of those of control animals (Denamur et al., 1966; Denamur, 1968). This relative maintenance is due to ovulatory surges of $\mathrm{LH}, \mathrm{FSH}$ and prolactin and not to incomplete hypophysectomy: separate or simultaneous administration of $20 \mathrm{ml}$ antiovine $\mathrm{LH}$ horse serum and $20 \mathrm{ml}$ antiprolactin horse serum for 10 days after the operation does not change the weight of the CL of the hypophysectomized ewes at Day 2 of the cycle. It may be presumed that follicular cells have acquired the ability to synthesize progesterone under the effect of the ovulatory surges of $\mathrm{LH}$ and prolactin. The exact contribution of prolactin during the ovulatory hormone surge is therefore not well known at present.

\section{Rôle of basal prolactin levels during the cycle}

Ergocryptine administered throughout the cycle from Day 2 after detection of heat does not prevent the appearance of another ovulation at the expected date and the presence of a normal corpus luteum, as Niswender (1972) has shown. However, in our hands and in the same conditions, plasma prolactin is lowered from the $6 \mathrm{hr}$ following the first CB-154 injection of $0.5 \mathrm{mg}$. As long as treatment lasts (18 days), basal prolactin levels are not more than 0.1 to $0.5 \mathrm{ng} / \mathrm{ml}$ and pre-ovulatory prolactin peaks do not appear, although the $\mathrm{LH}$ surge occurs normally. The corpus luteum which results from the ovulation preceding the beginning of treatment does not disappear more quickly after the large drop in plasma prolactin concentration. Thus, while this hormone is necessary for the maintenance of normal luteal structure (Denamur et al., 1970, 1973) there seems to be an excess of it during the cycle. Also, as Niswender (1972) indicates, the rôle of prolactin during ovulation does not appear to be fundamental since normal ovulation occurs in the absence of the pre-ovulatory prolactin surge.

Arguments for the rôle of prolactin in maintaining the corpus luteum of the non-pregnant ewe

First, the effects of prolactin supplementation in hypophysectomized ewes on Day 2 of the oestrous cycle are particularly instructive: prolactin without LH contamination (250 i.u. in four injections/day for 12 days) was given immediately after total hypophysectomy to ten ewes. The average weight of the CL was $407 \pm 91 \mathrm{mg}$ at the end of treatment compared to $247 \pm 23 \mathrm{mg}$ in the control hypophysectomized ewes.

Secondly, it is well known that luteal maintenance for 128 to 135 days follows hysterectomy of ewes at Day 9 to 12 of the oestrous cycle. In such ewes, prolactin levels during the 40 days after the operation are very similar to those of cycling animals not in oestrus. If animals are hypophysectomized after hysterectomy, luteal activity becomes almost undetectable in 4 days (Denamur et al., 1973). Such animals, hysterectomized between Days 9 and 12 of the cycle and hypophysectomized from 20 to 50 days later, are used to test the luteotrophic properties of ovine gonadotrophins. Prolactin (250 i.u. in four 
intramuscular injections/day for 12 days) maintains CL activity for at least 12 days but at a reduced level. $\mathrm{LH}$ alone, even at doses of $5 \mathrm{mg}$ /day, higher than those usually secreted by the cycling ewe, does not have this effect. It should be noted that if the same dose of prolactin is administered simultaneously with $0.25 \mathrm{mg} \mathrm{LH} /$ day, the corpus luteum (after 12 days of treatment) is no different from that of control animals that have been hysterectomized only (Denamur $e t$ $a l ., 1973)$. The luteotrophic rôle of the LH-prolactin association is thus demonstrated; while $\mathrm{LH}$ alone is completely ineffective, prolactin by itself permits some luteal activity to be maintained.

Thirdly, the luteotrophic rôle of prolactin is confirmed by pituitary stalksection experiments on Day 3 of the cycle (Denamur et al., 1966) : 12 days after stalk-section, the corpora lutea of these ewes are relatively well developed $(542 \pm 50 \mathrm{mg})$. After this hypothalamo-pituitary disconnection, our usual LH radioimmunoassay is not sensitive enough to demonstrate any LH in the plasma. If there is any remaining $\mathrm{LH}$ secretion after stalk-section, it must therefore be less than $0.15 \mathrm{ng} / \mathrm{ml}$. If anti-ovine $\mathrm{LH}$ serum is given to these animals $(20 \mathrm{ml} /$ day for 12 days) in order to inhibit the action of any LH secretion which may persist after pituitary stalk-section, luteal structures remain even more developed than after hypophysectomy on Day 2 of the cycle and examination 9 days after the operation (320 $\mathrm{mg} \pm 33$ against $247 \pm 23$ ). This weight difference is related to the appreciable amount of prolactin $(2$ to $10 \mathrm{ng} / \mathrm{ml})$ persisting after stalk-section (Bryant \& his co-authors, 1971). The $5 \%$ of pituitary cells remaining intact after stalk-section (Adams, Daniel \& Pritchard, 1963) are known to give a good response in terms of prolactin plasma levels to different hormonal stimuli such as oestrogens (Kann \& Denamur, 1973) or TRH (Kann et al., 1973).

Although the luteotrophic rôle of prolactin seems to be defined by the three types of experiments described above, cyclic luteolysis occurring every 17 days in the ewe does not correspond to a decrease of plasma prolactin concentration; the first signs of a decrease in luteal activity appear at about Days 13 to 14 in ewe (Stormshak et al., 1963; Short, 1964; Thorburn, Bassett \& Smith, 1969) and during this time, or a little later, prolactin reaches several peaks of high value.

\section{Is not prolactin luteolytic at the end of the cycle?}

The experiments of Grandison \& Meites (1972) and those of Wuttke \& Meites (1971) point to such a luteolytic rôle of prolactin in rat and mouse. The observations of Denamur et al. (1970) are relevant to this hypothesis: large quantities of oestrogen, injected into cycling ewes in the last third of the luteal phase, led to precocious luteolysis of the CL, whether the pituitary stalk was intact or not. However, while luteal involution occurs in intact animals in the presence of very large amounts of blood prolactin, in animals with a hypothalamo-pituitary disconnection, luteolysis is brought about in the presence of prolactin concentrations similar to those observed in the luteal phase of untreated cycling animals (Kann \& Denamur, 1973). Moreover, cycling animals which are treated with ergocryptine undergo perfectly normal luteolysis and return to oestrus at the expected date in spite of having very low plasma prolactin levels. 
The luteolytic action of oestradiol in the ewe cannot be related in a simple way to changes in prolactin or LH secretion (Kann \& Denamur, 1973). Uterine luteolysin (probably prostaglandin $F_{2 \alpha}$ ) is presumably the factor brought into play in precocious luteolysis due to oestrogens (Denamur \& Kann, 1973). If the main intervention mechanism of $\mathrm{PGF}_{2 \alpha}$ consists in an ovarian antagonism between anterior pituitary luteotrophic hormones and prostaglandins, the hypothesis of Behrman and his collaborators (Behrman, MacDonald \& Greep, 1971; Behrman, Orczyk, MacDonald \& Greep, 1970) must be considered. This ascribes the inhibitory actions of $\mathrm{PGF}_{2 \alpha}$ to the controlled synthesis by prolactin of cholesterol esters during steroidogenesis in the rat. To our knowledge, such a study had not been made on the ewe, but would allow confirmation of the necessity of prolactin for normal functioning of the corpus luteum.

Are waves of follicular growth during the luteal phase of the cycle related to plasma prolactin variations in the ewe?

There is good correlation between the plurality of oestrogenic peak activity in the plasma (Scaramuzzi, Caldwell \& Moor, 1970; Cox, Mattner \& Thorburn, 1971; Holst, Braden \& Mattner, 1972; Terqui et al., 1973) and the multiplicity of follicular growth phases described in the ewe. It is classic to relate these follicular activities to variations in FSH content. Recently, we have measured prolactin, LH (Kann, 1971a, b), FSH (Kerdelhué, Kann \& Jutisz, 1972) and oestradiol-17 $\beta$ (Terqui et al., 1973) in the plasma of two cycling ewes. A certain synchrony appears between variations of FSH, prolactin and oestradiol peaks. These preliminary results were not sufficiently numerous and their significance remains to be demonstrated, but prolactin as well as FSH might be related to follicular growth as McCracken, Baird \& Goding (1971) suggested.

\section{PROLAGTIN DURING GESTATION IN THE EWE}

\section{Prolactin levels}

This study was undertaken in order to clarify the conflicting results of several authors (Arai \& Lee, 1967; McNeilly, 1971; Davis, Reichert \& Niswender, 1971).

There is some individual variability in the profile of plasma prolactin concentration during gestation (Text-fig. 2). This variability does not seem to be related to the sex of the fetus, to the number of fetuses or to plasma ovarian steroid content. We observe no change in the levels of prolactin from Days 12 to 18 of pregnancy, contrary to that which takes place at the corresponding period in the oestrous cycle. During the first 3 months of gestation, there is relatively little prolactin in the plasma of pregnant ewes (3 to $18 \mathrm{ng} / \mathrm{ml}$ ), although secretion has a tendency to stay around the highest values in a rather constant way after Day 75 of gestation.

In five ewes out of seven, plasma prolactin content increased from Day 100 of gestation, in a progressive way, up to average values of 80 to $90 \mathrm{ng} / \mathrm{ml}$ reached 10 days before lambing. This coincided with an increase of oestradiol$17 \beta$. During the 10 days before parturition, prolactin secretion rose consider- 
ably in these five pregnant ewes. An average amount of 150 to $200 \mathrm{ng} / \mathrm{ml}$ was measured 3 days before lambing. The maximum average prolactin level $(682 \mathrm{ng} / \mathrm{ml})$ was observed at the same time as the oestrogen peak described by Challis (1971) $24 \mathrm{hr}$ before lambing (see Bedford, Challis, Harrison \& Heap, 1972). Maximum prolactin values were higher than $1 \mu \mathrm{g} / \mathrm{ml}$ at that time in two ewes. At the time of parturition, the average value of prolactin concentration drops to $450 \mathrm{ng} / \mathrm{ml}$ (Text-fig. 3).

In the other animals there was little variation in plasma prolactin or change in oestradiol-17 $\beta$ concentration before Day 142 of gestation, after which their prolactin secretion followed the same pattern as that of the other ewes. But after parturition the milk yield of the two animals mentioned was found to be much lower than that of the remaining ewes.

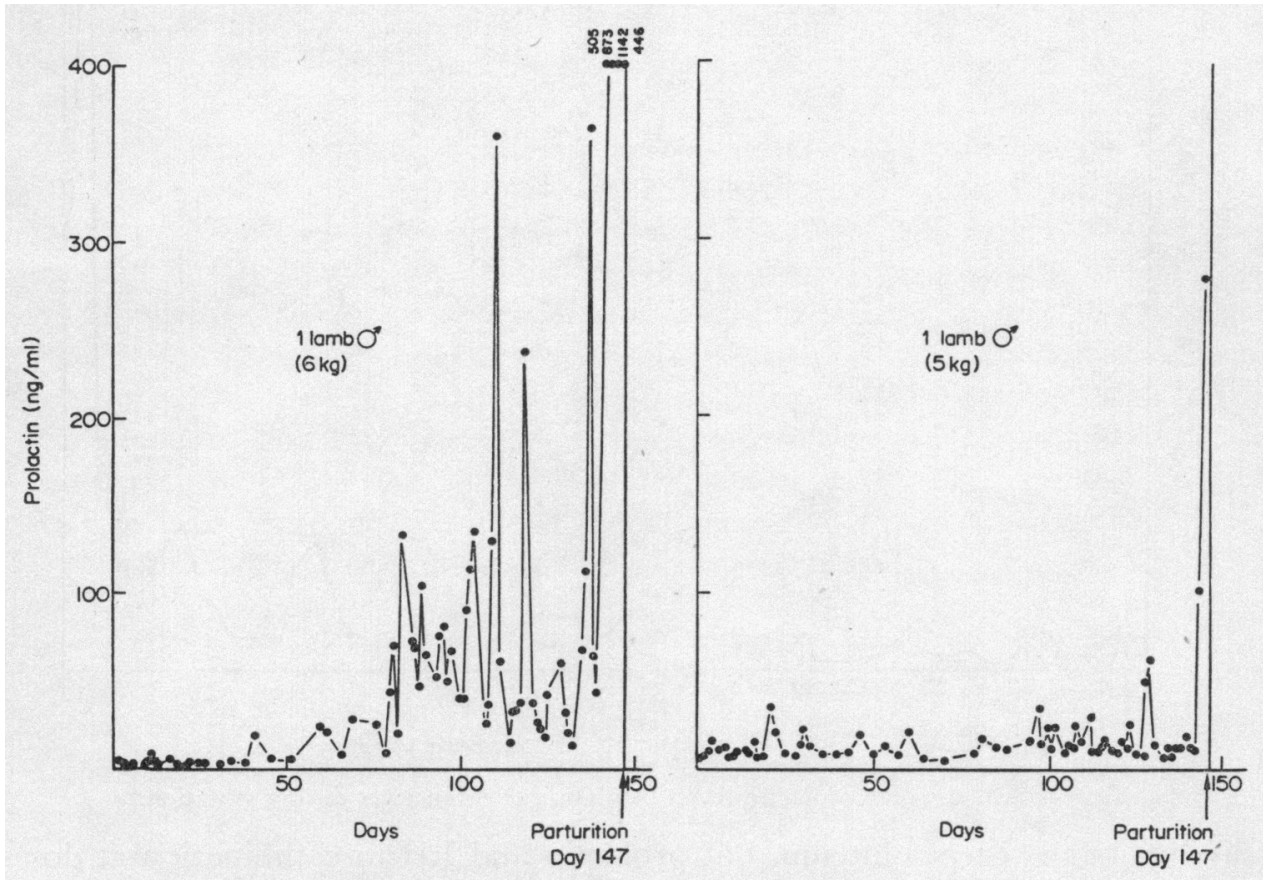

TeXT-Frg. 2. Prolactin concentration in plasma during gestation in a ewe with a high milk yield (left) and with a low milk yield (right) after parturition.

\section{Rôle of prolactin in gestation}

The luteotrophic and lactogenic action of pituitary prolactin may be demonstrated during gestation in the ewe, but prolactin is only one of the constituents of the luteotrophic complex, as well as being only one of the hormones belonging to the lactogenic complex in this species. Moreover, at the end of the 2nd month, placental luteotrophic and lactogenic factors intervene.

Prolactin belongs to the luteotrophic complex permitting the establishment of gestation Hypophysectomy on Day 3, 10 or 30 of gestation (before or after implanta- 
tion) caused abortion and the regression of luteal structures (Denamur \& Martinet, 1961; Denamur, 1968). Recent experiments have clarified the nature of the anterior pituitary hormones responsible, by means of hormonal supplementations after hypophysectomy or by the use of specific antibodies to neutralize elements of the luteotrophic complex.

Administration (250 i.u./day) of prolactin after hypophysectomy on Day 10 of gestation allowed reduced luteal structures to be maintained to Day 20 (391 $\pm 20 \mathrm{mg})$, abortion seeming close. LH $(0.5 \mathrm{mg} /$ day) did not lead to better

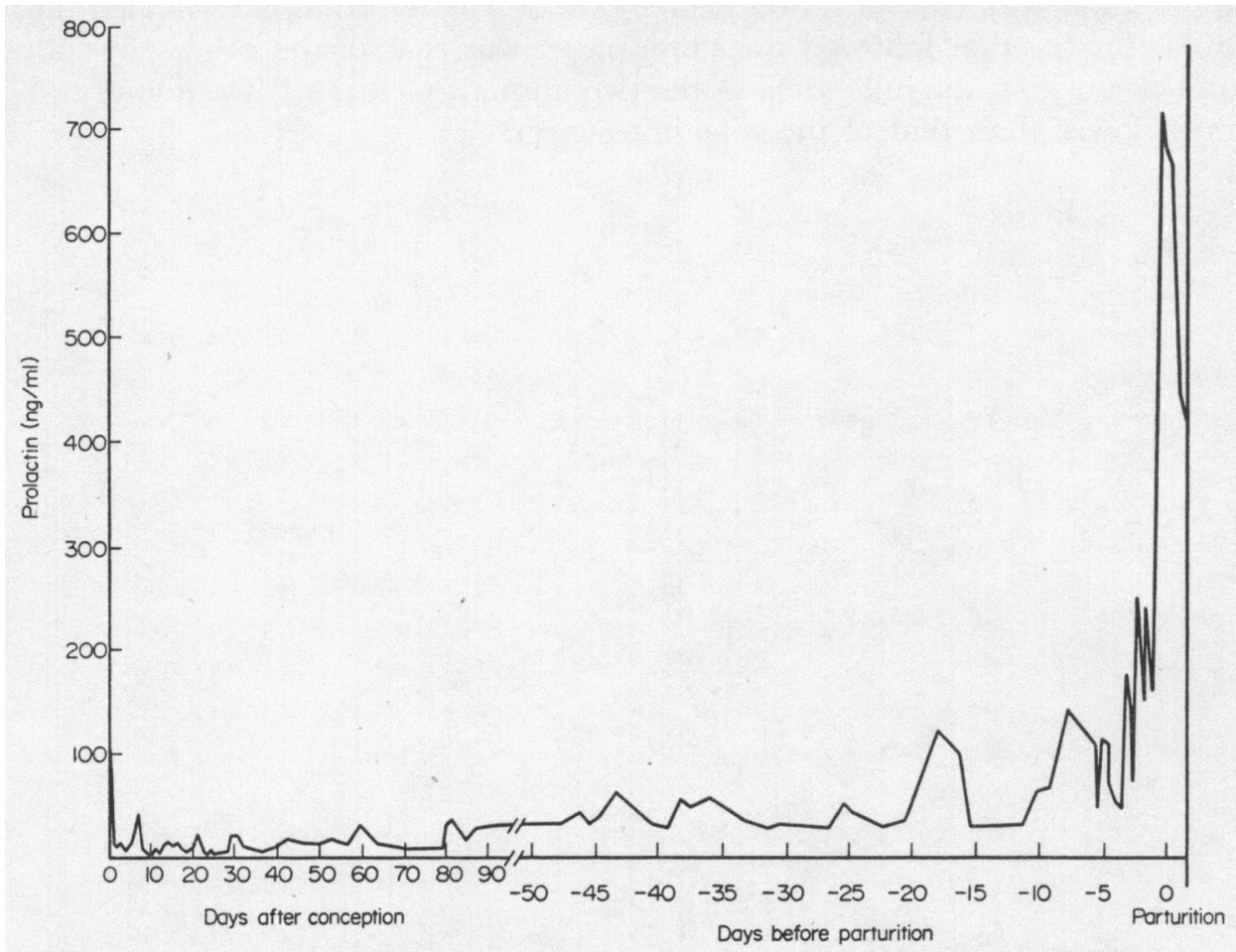

TeXT-FIg. 3. Average prolactin levels in plasma of seven ewes during gestation.

survival of the corpus luteum, but prolactin and LH in combination at doses indicated above, allowed normal development of the CL on Day $20(726 \pm 36$ $\mathrm{mg}$ ) and the survival of normal fetuses.

Simultaneous injection of anti-prolactin and anti-LH antibodies every day between Days 10 and 20 of gestation caused abortion, and regression of the GL, in intact pregnant animals. One of the two antibodies administered in the same conditions neither induced abortion nor lowered plasma progesterone concentration, but simply caused a decrease of CL weights from $620 \pm 80 \mathrm{mg}$ to $431 \pm 40 \mathrm{mg}$. During Days 30 to 42 of pregnancy, the two antibodies were ineffective even when injected simultaneously. After pituitary stalk-section on Day 10 of gestation, injection of one of the two immunosera caused regression of the CL, measured on Day 20, and $100 \%$ abortion. Control animals with a hypothalamo-pituitary disconnection maintained normal pregnancy (Denamur \& Martinet, 1961). 
When the operation was done on Day 30 of gestation, the CL being examined on Day 42, antiprolactin immunoserum injected as previously was completely ineffective and antiovine $\mathrm{LH}$ antibody caused abortion in only $50 \%$ of pregnant ewes. Different effects of antibody injection on intact or stalk-sectioned animals can only be attributed to the early presence of luteotrophic activity of fetoplacental origin.

The placental luteotrophic factor is not prolactin of fetal or placental origin: hypophysectomy of a pregnant ewe from Day 60 of gestation permits the corpus luteum to survive ( $75 \%$ of normal weight), but a few hours after the operation we can no longer show prolactin in the maternal plasma. The placental luteotrophic factor responsible for maintenance of luteal structures is thus not immunologically related to maternal pituitary prolactin.

Presence of prolactin during gestation seems to be necessary for establishment of normal lactation in the ewe

Working on hypophysectomized lactating ewes, R. Denamur, C. Delouis, M. Cannata \& J. Martinet (in prep.) showed that prolactin is a part of the ovine lactogenic complex, which includes cortisol, thyroxine, STH and prolactin. It is therefore logical to suppose that prolactin has a similar rôle in the last third of gestation, when the mammary gland presents some signs of secretory activity.

Delouis \& Denamur (1967) failed to induce milk secretion with 1200 i.u. ovine prolactin/day injected into pregnant ewes on Day 120, whereas cortisol (25 to $50 \mathrm{mg} /$ day) brought about some milk secretion. Thus prolactin is not the limiting factor determining the appearance of the mammary gland secretion during the end of pregnancy, in normal conditions.

However, the rapid increase of ribonucleic acids, and the appearance of lactose in the mammary gland extracts of the ewe, described by Denamur (1965) and Denamur \& Gaye (1967), occurs on Day 100 of pregnancy-the time when we observe a significant rise in prolactin levels in pregnant ewes.

Moreover, M. Cannata, C. Delouis, C. Jeulin \& R. Denamur (in preparation) demonstrated the rôle of prolactin in lactogenesis induced in vitro in mammary tissue from pregnant ewes. Biopsies of mammary tissue of primiparous ewes were taken between Days 80 and 90 of gestation. Explants $\left(1 \mathrm{~mm}^{3}\right)$, made at the time the samples were taken, were put in culture for 5 to 10 days on a synthetic medium (199) alone or with various hormonal combinations. If the tissue contained well formed acini with non-secretory alveoli, insulin, cortisol and purified prolactin in association (the somatotrophic contaminant being eliminated) induced milk secretion in acinar lumina after 5 days in culture. On the other hand, insulin and cortisol, administered in association, were ineffective, showing the essential rôle of prolactin for lactogenesis in vitro.

Dissimilarities between studies in vivo and the results of these experiments in vitro might be explained if one supposes that the lactogenic effect of prolactin during pregnancy is mostly hindered in vivo by an inhibitory effect of sex steroids, mainly progesterone.

\section{CONGLUSION}

Our results show that prolactin has a luteotrophic effect on cycling and pregnant 
ewes, and is a constituent of the luteotrophic complex, which includes LH. It seems that the normal secretion of prolactin is usually higher than this luteotrophic function requires. Study of the luteotrophic rôle of anterior pituitary hormones at the end of the first month of gestation reveals the progressive appearance of placental factors with LH (Goding \& his co-authors, 1972) and prolactin (Buttle, Forsyth \& Knaggs, 1972; Forsyth, 1973) activities.

Studies undertaken in vitro tend to demonstrate the important rôle of prolactin in the establishment of lactogenesis in the ewe during gestation. Further experiments are necessary to define the mode of action of prolactin on the mammary gland and its relation to that of steroid hormones.

\section{AGKNOWLEDGMENTS}

We would like to thank Professor M. Jutisz for supplying the C.N.R.S. hormones, Dr E. Flückiger for supplying ergocryptine, and Mrs Danielle Drouet and Miss Chantal Meusnier for their valuable technical assistance.

\section{REFERENGES}

Adams, J. H., Daniel, P. M. \& Pritchard, M. M. (1963) The effect of stalk section on the volume of the pituitary gland of the sheep. Acta endocr., Copenh. 43, Suppl. 81.

ARAI, Y. \& LEe, T. H. (1967) A double radioimmunoassay procedure for ovine pituitary prolactin. Endocrinology, 81, 1041.

Bedford, G. A., Challis, J. R. G., Harrison, F. A. \& Heap, R. B. (1972) The rôle of oestrogens and progesterone in the onset of parturition in various species. $\mathcal{F}$. Reprod. Fert., Suppl. $16,1$.

Behrman, H. R., MacDonald, G. J. \& GreeP, R. O. (1971) Regulation of ovarian cholesterol esters: evidence for the enzymatic sites of prostaglandin induced loss of corpus luteum function. Lipids, 6, 791.

Behrman, H. R., Orczyk, G. P., MacDonald, G. J. \& Greep, R. O. (1970) Prolactin induction of enzymes controlling luteal cholesterol ester turnover. Endocrinology, 87, 1251.

Bjersing, L., Hay, M. F., Kann, G., Moor, R. M., Naftolin, F., Scaramuzzi, R. J., Short, R. V. \& Young LAI, E. V. (1972) Changes in gonadotrophins, ovarian steroids and follicular morphology in sheep at oestrus. F. Endocr. 52, 465 .

Bryant, G. D., Greenwood, F. C., Kann, G., Martinet, J. \& Denamur, R. (1971) Plasma prolactin in the oestrous cycle of the ewe: effect of pituitary stalk section. 7 . Endocr. 51, 405.

Buttle, H. L., Forsyth, I. A. \& Knaggs, G. S. (1972) Plasma prolactin measured by radioimmunoassay and bioassay in pregnant and lactating goats and the occurrence of a placental lactogen. 7. Endocr. 53, 483.

Challis, J. R. G. (1971) Sharp increase in free circulating oestrogens immediately before parturition in sheep. Nature, Lond. 229, 208.

Cox, R. I., Mattener, P. E. \& ThorburN (1971) Changes in ovarian secretion of oestradiol-17 $\beta$ around oestrus in the sheep. F. Endocr. 49, 345.

Gumming, I. A., Brown, J. M., Goding, J. R., Bryant, G. D. \& Greenwood, F. Y. (1972) Secretion of prolactin and luteinizing hormone at oestrus in the ewe. 7. Endocr. 54, 207.

Davis, S. L., Reichert, L. E., JR \& Niswender, G. D. (1971) Serum levels of prolactin in sheep as measured by radioimmunoassay. Biol. Reprod. 4, 145.

Dezouis, G. \& Denamur, R. (1967) Induction expérimentale de la sécrétion lactée pendant la gestation de la brebis. C. r. hebd. Séanc. Acad. Sci., Paris, 264, 2493.

Denamur, R. (1965) Les acides nucléiques et les nucléotides libres de la glande mammaire pendant la lactogénèse et la galactopoìèse. Proc. 2nd Int. Congr. Endocr., London, Excerpta Med. Int. Congr. Ser. 83, 434 .

Denamur, R. (1968) Formation and maintenance of corpora lutea in domestic animals. J. Anim. Sci. 27, Suppl. 1, 163.

Denamur, R. \& Gaye, P. (1967) Les acides ribonucléiques de la glande mammaire au cours de l'induction et de l'entretien de la sécrétion lactée. Archs Anat. microsc. Morph. exp. 56, Suppl. 3-4, 596.

Denamur, R. \& KanN, G. (1973) Luteolytic effects of oestradiol after hypophysectomy or pituitary stalk section in cycling sheep. Acta endocr., Copenh. 73, 635. 
Denamur, R. \& Martinet, J. (1961) Effets de l'hypophysectomie de la section de la tige pituitaire sur la gestation de la brebis. Annls Endocr. 22, 755.

Denamur, R., Martinet, J. \& Short, R. V. (1966) Secrétion de la progestérone par les corps jaunes de la brebis après hypophysectomie, section de la tige pituitaire et hysterectomie. Acta endocr.: Copenh. 52, 72.

Denamur, R., Martinet, J. \& Short, R. V. (1970) Mode of action of oestrogen in maintaining the functional life of corpora lutea in sheep. 7. Reprod. Fert. 23, 109.

Denamur, R., Martinet, J. \& Short, R. V. (1973) Pituitary control of the ovine corpus luteum. J. Reprod. Fert. 32, 207.

ForsyTH, I. A. (1973) Secretion of a prolactin-like hormone by the placenta in ruminants. In Colloque de la Société National pour l'Etude de la Stérilité et de la Fécondité: Le Corps Jaune, p. 239. Masson et Cie, Paris.

Goding, J. R., Buckmaster, J. M., Gerini, J. G., Cerini, M. E. D., Chamley, W. A., Gumming, I. A., Fell, L. R., Findlay, J. K. \& Jonas, H. (1972) Gonadotrophins in the ovine oestrous cycle. 7. Reprod. Fert., Suppl. 18, 31.

Grandison, L. \& MeItes, J. (1972) Luteolytic action of prolactin during the estrous cycle of the mouse. Proc. Soc. exp. Biol. Med. 140, 323.

Holst, P. J., Braden, A. W. H. \& Matrner, P. E. (1972) Oestradiol-17 $\beta$ secretion from the ewe ovary and related ovarian morphology on Days 2 and 3 of the cycle. $\mathcal{F}$. Reprod. Fert. 28, 136.

KANN, G. (1971a) Dosage radio-immunologique de la prolactine plasmatique chez les ovins. C. r. hebd. Seanc. Acad. Sci., Paris, 272, 2808.

KANN, G. (1971b) Variations des concentrations plasmatiques de l'hormone lutéinisante et de la prolactine au cours du cycle oestrien de la brebis. C. r. hebd. Séanc. Acad. Sci., Paris, 272, 2934.

Kann, G. \& Denamur, R. (1973) Changes in plasma levels of prolactin and LH induced by luteolytic or luteotrophic oestrogen treatment in intact cycling sheep or in sheep after section of the pituitary stalk. Acta endocr., Copenh. 73, 625.

Kann, G., Habert, R. \& Denamur, R. (1973) Concentrations plasmatiques de la prolactine et de l'hormone thyreostimulante au cours de la traite des brebis, comparaison avec les effets du T.R.F. C. r. hebd. Séanc. Acad. Sci., Paris, 296, 1321.

Kerdelhut, B., KanN, G. \& Jutisz, M. (1972) Dosage radioimmunologique de la F. S. H. chez le mouton et le rat. In Hormones Glycoprotéiques Hypophysaires, p. 177. Inserm, Paris.

Lyons, W. R., Lr, C. H. \& Johnson, R. E. (1958) The hormonal control of mammary growth and lactation. Recent Prog. Horm. Res. 14, 219.

McCracken, J. A., Baird, D. T. \& Goding, J. R. (1971) Factors affecting the secretion of steroids from the transplanted ovary of the sheep. Recent Prog. Horm. Res. 27, 537.

McNeILLY, J. R. (1971) A solid phase radioimmunoassay for ovine prolactin. F. Endocr. 49, 141.

Niswender, G. D. (1972) The effect of ergocornine on reproduction in sheep. Biol. Reprod. 7, 138.

Riddle, O., Bates, R. W. \& Dykshorn, S. W. (1933) The preparation, identification and assay of prolactin - a hormone of the antierior pituitary. Am. F. Physiol. 105, 191.

Scaramuzzi, R. J., Caldweld, B. V. \& Moor, R. M. (1970) Radioimmunoassay of LH and estrogen during the estrous cycle of the ewe. Biol. Reprod. 3,110.

Short, R. V. (1964) Ovarian steroid synthesis and secretion in vivo. Recent Prog. Horm. Res. 20, 303.

Stormshax, F., Inskeep, E. K., Lynn, J. E., Pope, A. L. \& Gasida, L. E. (1963) Progesterone levels in corpora lutea and ovarian effluent blood of the ewe. J. Anim. Sci. 22, 1021.

Stricker, P. \& Gruether, F. (1928) Action du lobe antérieur de l'hypophyse sur la montée laiteuse. C. r. Séanc. Soc. Biol. 99, 1978.

Strigker, P. \& Gruether, F. (1929) Recherches expérimentales sur les fonctions du lobe antérieur de l'hypophyse: influence des extraits du lobe antérieur sur l'appareil génital de la lapine et sur la montée laiteuse. Presse méd. 37, 1268.

Terqui, M., Dray, F. \& CotTa, J. (1973) Variations de l'oestradiol-17 $\beta$ dans le sang périphérique au cours du cycle oestral chez la brebis. C. r. hébd. Séanc. Acad. Sci., Paris, 277, 1795.

Thorburn, G. D., Bassetr, J. M. \& Sмith, I. D. (1969) Progesterone concentration in the periphera plasma of sheep during the oestrous cycle. 7 . Endocr. 45, 459.

WutTke, W. \& MEITEs, J. (1971) Luteolytic role of prolactin during the estrous cycle of the rat. Proc. Soc. exp. Biol. Med. 137, 988. 